\section{Visual Quality, Gas Exchange, and Yield of Anemone and Ranunculus Irrigated with Saline Water}

\author{
Shannon Rauter ${ }^{1}$, Youping Sun ${ }^{1}$, and Melanie Stock ${ }^{1}$
}

AdDitional Index wORDs. Anemone coronaria, cut flower, Ranunculus asiaticus, salinity, visual score

SUMMARY. In response to the growing demand for specialty cut flowers, floral crops are increasingly produced in semiarid areas where soil salinity can impact crop timing, reduce stem length, and decrease yield. The goal of this study was to investigate the salinity sensitivity of 'Carmel' and 'Galilee' anemone (Anemone coronaria), and 'Amandine' and 'LaBelle' ranunculus (Ranunculus asiaticus) with respect to physiological characteristics and marketable yield. Nine plants were irrigated weekly for 8 weeks with a nutrient (control) solution with an electrical conductivity (EC) of $0.5 \mathrm{dS} \cdot \mathrm{m}^{-1}$ or saline solutions prepared by adding sodium chloride and calcium chloride dihydrate to a nutrient solution to obtain an EC of 1.5, 2.5, 3.5, 4.5, or 5.5 $\mathrm{dS} \cdot \mathrm{m}^{-1}$. Yield was evaluated by dividing stems into marketable and cull grades based on length and bloom quality. At the end of the study, the visual quality of the plants was scored, and gas exchange data were collected using a portable photosynthesis system. Cultivars of each species responded similarly, and marketable yields were low across all treatments, with average marketable yields (mean \pm SD) of $1.7 \pm 0.6$ stems /plant for anemone and $1.2 \pm 0.1$ stems/plant for ranunculus. Visual quality $(0-5$ scale, with $0=$ dead and 5 = excellent) decreased from 3 to 1 for anemone and 3 to 2 for ranunculus as EC increased from 0.5 to $4.5 \mathrm{dS} \cdot \mathrm{m}^{-1}$ and 0.5 to $5.5 \mathrm{dS} \cdot \mathrm{m}^{-1}$, respectively. Anemone leaf greenness decreased by $48 \%$, stomatal conductance $\left(g_{s}\right)$ decreased by $79 \%$, transpiration $(E)$ decreased by $75 \%$, and net photosynthesis $\left(P_{n}\right)$ decreased by $92 \%$ when irrigation solution EC increased from 0.5 to $4.5 \mathrm{dS} \cdot \mathrm{m}^{-1}$. The ranunculus growth index decreased by $17 \%$, leaf greenness decreased by $45 \%$, and $E$ decreased by $23 \%$ as irrigation solution EC increased from 0.5 to $5.5 \mathrm{dS} \cdot \mathrm{m}^{-1}$. Both anemone and ranunculus can be considered sensitive to salinity, indicating the importance of careful soil management in cut flower production systems in semiarid areas that are at risk for elevated soil salinity.

Received for publication 6 Aug. 2021. Accepted for publication 13 Sept. 2021

Published online 27 October 2021

${ }^{1}$ Department of Plants, Soils, and Climate, Utah State University, 4820 Old Main Hill, Logan, UT 84322

This research was supported in part by a Utah Department of Agriculture and Food Specialty Crop Block Grant, the Association of Specialty Cut Flower Growers, and a U.S. Department of Agriculture National Institute of Food and Agriculture National Needs Fellowship. This research was also supported by the Department of Plants, Soils, and Climate, and the Utah Agricultural Experiment Station, Utah State University, and approved as journal paper no. 9517

We thank Claudia Nischwitz, Nick Volesky, Kasey Battson, and Anna Collins for their technical assistance; and Amita Kaundal and Asmita Paudel for their review of this manuscript.

The content is solely the responsibility of the authors and does not necessarily represent the official views of the funding agencies. Mention of a trademark, proprietary product, or vendor does not constitute a guarantee or warranty of the product by the U.S. Department of Agriculture or the American Society for Horticultural Science and does not imply its approval to the exclusion of other products or vendors that also may be suitable.

S.R. is the corresponding author. E-mail: shannon. rauter@usu.edu.

This is an open access article distributed under the CC BY-NC-ND license (https://creativecommons. org/licenses/by-nc-nd/4.0/).

https://doi.org/10.21273/HORTTECH04930-21
S oil salinity is a common problem in arid and semiarid environments, with elevated levels of salts naturally occurring in the root zone or accumulating from external sources, such as irrigation water, fertilizers, manures, or composts (Bugbee, 2002; Pitman and Läuchli, 2002; Tanji, 2002). Salinity impacts crops physiologically by altering water and nutrient absorption, membrane permeability, plant metabolism, hormone balance, gas exchange, reactive oxygen species production, and cell elongation and division (Prisco et al., 2016). Collectively, these changes can modify vegetative and reproductive growth, and affect key agronomic factors such as crop timing (Grieve et al., 1994), quality (Maas and Grattan, 1999), and yield (Maas and Hoffman, 1977).

For the past three decades, the U.S. cut flower industry has adapted to increases in inexpensive floral imports by focusing on the production of specialty flowers that are difficult to ship long distances and marketing locally grown flowers (Armitage and Laushman, 2003; Kelly, 1991; Stewart, 2007; Yue and Hall, 2010). In Utah and southern Idaho alone, 86 small-scale cut flower farms have been established (Lewis et al., 2021). Production of cut flowers in semiarid areas with high soil salinity and/or low-quality irrigation water faces challenges with cut flower salt sensitivity. Most specialty cut flowers are generally classified as sensitive to soil and irrigation water salinity and, therefore, are avoided as potential crops for saline soils or water reuse systems (Carter and Grieve, 2008). In floral crops specifically, salinity can advance or delay time to harvest, reduce stem length, impact bloom quality, and reduce yield (Carter and Grieve, 2008; Grieve, 2011; Grieve et al., 2008; Shillo et al., 2002). However, some cut flower species are moderately salt tolerant. Limonium (Limonium sp.) and stock (Matthiola incana) produced marketable stems with no significant decrease in yield when irrigated with water of an EC up to 11.5 and $8.0 \mathrm{dS} \cdot \mathrm{m}^{-1}$, respectively (Carter and Grieve, 2008; Shillo et al., 2002).

As U.S. specialty cut flower production continues to expand into areas with salinity challenges, screening additional floricultural crops for salt tolerance becomes important from the perspectives of both economic and environmental sustainability. A variety of metrics can be useful for assessing plant responses to salinity, including plant growth, visual qualify, leaf greenness,

\begin{tabular}{llll}
\hline $\begin{array}{l}\text { Units } \\
\text { To convert U.S. to SI, } \\
\text { multiply by }\end{array}$ & U.S. unit & SI unit & $\begin{array}{l}\text { To convert SI to U.S., } \\
\text { multiply by }\end{array}$ \\
\hline 29.5735 & $\mathrm{fl} \mathrm{oz}$ & $\mathrm{mL}$ & 0.0338 \\
0.3048 & $\mathrm{ft}$ & $\mathrm{m}$ & 3.2808 \\
3.7854 & $\mathrm{gal}$ & $\mathrm{L}$ & 0.2642 \\
2.54 & inch $(\mathrm{es})$ & $\mathrm{cm}$ & 0.3937 \\
1 & $\mathrm{mmho} / \mathrm{cm}$ & $\mathrm{dS} \cdot \mathrm{m}^{-1}$ & 1 \\
28.3495 & $\mathrm{Oz}$ & $\mathrm{g}$ & 0.0353 \\
0.001 & $\mathrm{ppm}$ & $\mathrm{g} \cdot \mathrm{L}^{-1}$ & 1000 \\
1 & $\mathrm{ppm}$ & $\mathrm{mg} \cdot \mathrm{L}^{-1}$ & 1 \\
$\left({ }^{\circ} \mathrm{F}-32\right) \div 1.8$ & ${ }^{\circ} \mathrm{F}$ & ${ }^{\circ} \mathrm{C}$ & $\left({ }^{\circ} \mathrm{C} \times 1.8\right)+32$
\end{tabular}

Horflechnology $\cdot$ December $202131(6)$ 
and gas exchange measurements (Niu and Cabrera, 2010). The size of leaves, stems, roots, and flowers may be reduced because of salinity stress. Beyond the primary implication of reduced growth decreasing plant productivity, the length and number of stems, and size of blooms are particularly important for cut flowers, making growth index a potentially useful metric for connecting salinity stress to marketability.

Anemone (Anemone coronaria) and ranunculus (Ranunculus asiaticus) are cool-season perennials belonging to the buttercup family (Ranunculaceae) that are typically cultivated as annuals for cut flower production (De Hertogh, 1996). Valdez-Aguilar et al. (2009) found 'Yellow ASD' and 'Pink CTD' ranunculus to be hypersensitive to salinity, with the number of flowering stems produced per plant decreasing from 2.9 to 0.8 stems/plant and 3.2 to 0.8 stems/plant for each cultivar, respectively, when irrigation solution increased from 2.0 to $6.0 \mathrm{dS} \cdot \mathrm{m}^{-1}$. Irrigation solution salinities less than $2.0 \mathrm{dS} \cdot \mathrm{m}^{-1}$ were not evaluated for ranunculus, allowing the possibility that the salinity tolerance threshold for ranunculus could be less than an EC of $2.0 \mathrm{dS} \cdot \mathrm{m}^{-1}$. To date, research has not been conducted regarding the salinity tolerance of anemone. Therefore, the objective of this study was to evaluate the effect of saline irrigation solutions on physiological characteristics and marketable yield of anemone and ranunculus cut flowers.

\section{Materials and methods}

Plant materials and culture. This trial was conducted at the Utah State University Research Greenhouse in Logan, UT (lat. $41^{\circ} 45^{\prime} 28^{\prime \prime} \mathrm{N}$, long. $111^{\circ} 48^{\prime} 48^{\prime \prime} \mathrm{W}$; elevation, $1409 \mathrm{~m}$ ). Tubers of 'Carmel' and 'Galilee' anemone (size, 5-6 cm) and tuberous roots of 'Amandine' and 'LaBelle' ranunculus (size, 5-7 cm) were obtained from a commercial supplier (Fred C. Gloeckner and Co., Harrison, NY) on 25 Oct. 2020. For simplicity, both tuberous roots and tubers are referred to as tubers when discussed together. Until the experiment was conducted, tubers were stored in dark conditions at 11 to $13{ }^{\circ} \mathrm{C}$ and an average relative humidity of $50 \%$ (Cerveny et al., 2011; De Hertogh, 1996).

On 15 Jan. 2021, tubers were soaked in slowly running 15 to $25^{\circ} \mathrm{C}$ tap water for $12 \mathrm{~h}$, and a pump was used to aerate the water once per hour (Cerveny et al., 2012; Wien, 2015). For the last $20 \mathrm{~min}$ of soaking, the tubers were drained and submerged in a $0.3 \%$ Captan fungicide solution (BONIDE Products, Oriskany, NY), as recommended by the tuber supplier. The tubers were drained and placed in flats filled with a moist soilless growing medium consisting of $68 \%$ peatmoss (Canadian sphagnum peatmoss; Sun Gro Horticulture, Agawam, MA), 32\% vermiculite (ThermO-Rock West, Chandler, AZ), 0.48 $\mathrm{g} \cdot \mathrm{L}^{-1}$ wetting agent (AquaGro 2000 G; Aquatrols, Paulsboro, NJ), and $1.43 \mathrm{~g} \cdot \mathrm{L}^{-1}$ hydrated lime (Mississippi Lime, St. Louis, MO). The flats were stored in a cooler for 2 weeks at $4{ }^{\circ} \mathrm{C}$ (Ohkawa, 1986). After cold treatment, on 29 Jan. 2021, the tubers were transplanted into 1-gal injection-molded polypropylene containers (PCID-4; Nursery Supplies, Orange, CA) filled with soilless growing media of the recipe described and placed in a greenhouse. The day/ night temperature in the greenhouse was maintained at $22 / 18^{\circ} \mathrm{C}$ until $25 \mathrm{Mar}$. 2021 , when it was adjusted to $20 / 16^{\circ} \mathrm{C}$ to discourage tuberization (De Hertogh and Le Nard, 1993). Light intensities were recorded hourly using a heated silicon chip pyranometer (SP-230; Apogee Instruments, Logan, UT) mounted to a weather station at the Utah Agricultural Experiment Station's Greenville Research Farm (North Logan), $\approx 1000$ m away from the greenhouse. A light transmission rate of $68 \%$ was used when calculating the daily light integral inside the greenhouse, and the daily light integral was (mean \pm SD) $25.6 \pm 11.5$ $\mathrm{mol} \cdot \mathrm{m}^{-2} \cdot \mathrm{d}^{-1}$ from 29 Jan. to $30 \mathrm{Apr}$. 2021. Supplemental light, measured with a quantum meter (SQ-120, Apogee Instruments), at $153.3 \mu \mathrm{mol} \cdot \mathrm{m}^{-2} \cdot \mathrm{s}^{-1}$, was provided using 1000-W high-pressure sodium lamps (Gavita, Vancouver, WA) from 600 to $2200 \mathrm{HR}$ when light intensity inside the greenhouse was less than $500 \mu \mathrm{mol} \cdot \mathrm{m}^{-2} \cdot \mathrm{s}^{-1}$.

Salinity treatments. A total of 108 ranunculus and 54 anemones were grown in individual pots for 6 weeks before initiating salinity treatments on 10 Mar. 2021. Six salinity treatments were tested on ranunculus that included an irrigation solution at ECs of 0.5 (control), 1.5, 2.5, 3.5, 4.5 , and $5.5 \mathrm{dS} \cdot \mathrm{m}^{-1}$. Three salinity treatments-of 0.5 (control), 2.5, and
$4.5 \mathrm{dS} \cdot \mathrm{m}^{-1}$ irrigation solution-were used to test anemone because of the limited number of plants available for the study.

The nutrient (control) solution was prepared in a $100-\mathrm{L}$ tank by adding $0.4 \mathrm{~g} \cdot \mathrm{L}^{-1} 15 \mathrm{~N}-2.2 \mathrm{P}-12.5 \mathrm{~K}$ water-soluble fertilizer (Peters Excel 15-5-15 Cal-Mag Special; ICL Specialty Fertilizers, Dublin, $\mathrm{OH}$ ) to reverse-osmosis water. The saline solutions were prepared with an addition of sodium chloride and calcium chloride dihydrate (Fisher Chemical, Logan, UT) at a molar ratio of 2:1 in the nutrient solution (Niu and Cabrera, 2010). The initial $\mathrm{pH}$ of the solutions was adjusted to 6.0 to 6.5 by adding $88 \%$ potassium hydroxide pellets or $1 \mathrm{~m}$ nitric acid as needed (De Hertogh, 1996). The sodium adsorption ratio and elemental analysis were confirmed by the Utah State University Analytical Laboratory (Table 1). The ECs of the solutions, measured using an EC meter (LAQUA Twin; Horiba, Kyoto, Japan), were 0.59 \pm 0.03 (control nutrient solution), 1.44 $\pm 0.08\left(\mathrm{EC} 1.5 \mathrm{dS} \cdot \mathrm{m}^{-1}\right), 2.45 \pm 0.08$ $\left(\right.$ EC $\left.2.5 \mathrm{dS} \cdot \mathrm{m}^{-1}\right), 3.53 \pm 0.05($ EC 3.5 $\left.\mathrm{dS} \cdot \mathrm{m}^{-1}\right), 4.49 \pm 0.05\left(\right.$ EC $\left.4.5 \mathrm{dS} \cdot \mathrm{m}^{-1}\right)$, and $5.41 \pm 0.08 \mathrm{dS} \cdot \mathrm{m}^{-1}$ (EC 5.5 $\left.\mathrm{dS} \cdot \mathrm{m}^{-1}\right)$ during the experiment. Salinity treatments were applied once per week for 8 weeks by administering between 0.5 and $1.0 \mathrm{~L}$ of solution to each plant to obtain a target leaching fraction of $\approx 25 \%$. In between treatments, plants were watered with an additional $500 \mathrm{~mL}$ of control solution, as necessary, to avoid drought conditions.

Data collection. The EC of the leachate of the same two replications per treatment (i.e., 24 ranunculus and 12 anemone plants total) was measured weekly using the PourThru method (Cavins et al., 2008). Flower harvest was carried out daily or every other day as needed from 15 Mar. to 28 Apr. 2021, with each stem assigned a grade based on length and quality. Based on local market preferences and seasonality, straight stems a minimum of $15 \mathrm{~cm}$ in length were considered marketable, whereas cull stems were any stems shorter than $15 \mathrm{~cm}$, with excessive curvature, or with visible deformities (A. Harrison, personal communication). A visual score of 0 to 5 was assigned to each plant every 2 weeks and at the end of the experiment based on the guidelines used by Sun et al. (2015). A score of 
Table 1. The chemical compositions of a nutrient solution at an electrical conductivity (EC) of $0.5 \mathrm{dS} \cdot \mathrm{m}^{-1}(\mathrm{control})$ and saline solutions at ECs of $1.5,2.5,3.5,4.5$, or $5.5 \mathrm{dS} \cdot \mathrm{m}^{-1}$ used to irrigate anemone and ranunculus in a Utah greenhouse in 2021.

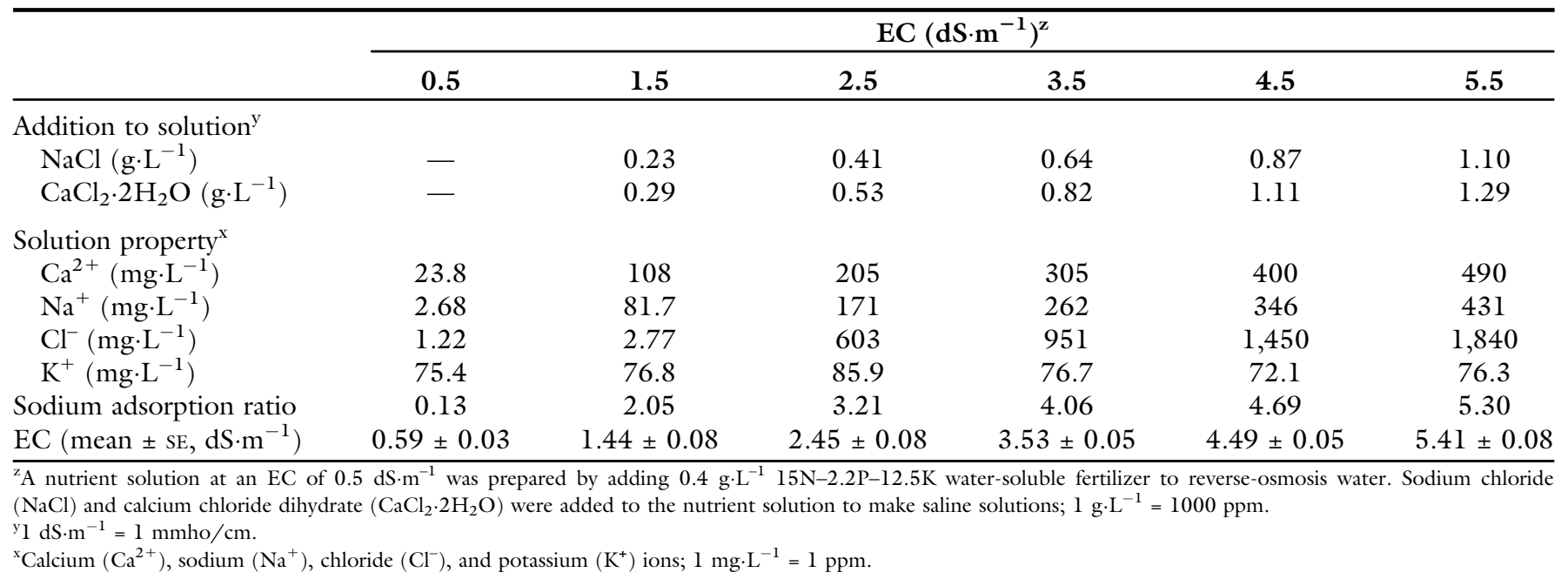

$0=$ dead, 1 = severe foliar damage (>90\% leaves with burnt edges, necrosis, or yellowing), 2 = moderate foliar damage $(50 \%$ to $90 \%), 3$ = slight foliar damage $(10 \%$ to $50 \%), 4=$ minimal foliar damage $(<10 \%)$, and $5=$ excellent, without foliar damage. Plant size was not considered when assigning the visual score.

During the study, plants were tested for Tomato spotted wilt virus, a widespread plant virus that is responsible for heavy economic losses in both horticultural and floral crops (Parrella et al., 2003). A total of $20.4 \%$ of the anemone and $5.6 \%$ of the ranunculus plants tested positive for Tomato spotted wilt virus and were excluded from statistical analysis. At the end of the experiment, leaf length, two canopy widths, leaf number, and leaf greenness were measured for all living plants. Leaf length and canopy widths were averaged to calculate a growth index [growth index $=$ (leaf length + width $1+$ width 2)/3] for each plant. Leaf greenness was measured using a handheld chlorophyll meter (MC-100, Apogee Instruments). Gas exchange measurements were collected at the end of the experiment for all living plants using a portable photosynthesis system (LI6800; LI-COR Biosciences, Lincoln, $\mathrm{NE}$ ). After taking all measurements, all plants were harvested and placed in a dryer at $60^{\circ} \mathrm{C}$ for $48 \mathrm{~h}$ before measuring shoot dry weight. At the end of the study, all tubers were examined visually for an unidentified root rot, with $20.4 \%$ of the anemone and $3.7 \%$ of the ranunculus plants affected. All plants with root rot were excluded from data analysis. The pots containing soilless media were left to dry for $10 \mathrm{~d}$ to encourage upward movement of salts before EC of the soilless media from the top $5 \mathrm{~cm}$ of each pot was measured using the saturated paste method outlined by Gavlak et al. (1994).

EXPERIMENTAL DESIGN AND DATA ANALYSES. The experiment was conducted using a randomized complete block design with nine blocks. Plants were arranged into blocks and placed on different benches in the greenhouse to account for the effects of microclimate and lighting differences within the greenhouse. Each block consisted of 12 ranunculus plants and six anemone plants (i.e., two ranunculus cultivars with six treatments each and two anemone cultivars with three treatments each). Both cultivars for each species responded similarly during the study, so all data were pooled across cultivars before analyses. Analysis of variance was performed for all plant growth and gas exchange parameters, and results were evaluated for statistical significance at $\alpha$ $=0.05$. Linear and quadratic trend analysis was performed. All statistical analyses were performed using JMP (version 13.2; SAS Institute, Cary, NC).

\section{Results and discussion}

Plant growth and visual QUALITY. Average leaf number (mean $\pm \mathrm{SD}$ ) was $8.5 \pm 0.9$ for anemone and $14.0 \pm 0.6$ for ranunculus, with no significant differences observed across salinity treatments (Table 2). Leaf number is typically determined by the size of the tuber, with larger tubers producing more shoots (Ben-Hod et al., 1989). Consequently, leaf number is likely not a reliable metric of salinity stress for tuberous plants. However, the growth index decreased linearly for ranunculus from 20.0 to $16.6 \mathrm{~cm}$ as EC increased from 0.5 to $5.5 \mathrm{dS} \cdot \mathrm{m}^{-1}(P=0.002)$. The growth index for anemone decreased from 21.1 to $18.8 \mathrm{~cm}$ as $\mathrm{EC}$ increased from 0.5 to $4.5 \mathrm{dS} \cdot \mathrm{m}^{-1}$ but was not affected by salinity significantly. Limited growth is an expected result of salinity stress (Munns and Tester, 2008) and has been observed in other cut flower species in the form of decreased plant height and shoot dry weight (Carter and Grieve, 2008).

The average shoot dry weight was $4.2 \pm 0.3 \mathrm{~g}$ for anemone and $2.5 \pm 0.2$ $\mathrm{g}$ for ranunculus, with no significant differences observed across treatments. In contrast, Valdez-Aguilar et al. (2009) found that increasing EC from 2 to $3 \mathrm{dS} \cdot \mathrm{m}^{-1}$ induced an $81 \%$ decrease in shoot dry weight across ranunculus cultivars, but additional EC increases did not result in additional shoot dry weight reductions. Valdez-Aguilar et al. (2009) initiated irrigation treatments 1 week after transplanting 3inch-tall seedlings, whereas in our study irrigation treatments began when plants were 6 weeks old and nearly at the flowering stage. Shoot dry weight is a less useful metric for salinity tolerance when irrigation treatments are applied just before flowering, as anemone 
Table 2. Leaf number, growth index [(leaf length + width $1+$ width 2$) / 3$ ], shoot dry weight (DW), chlorophyll content index $(\mathrm{CCI})$, stomatal conductance $\left(g_{\mathrm{s}}\right)$, transpiration rate $(E)$, and net photosynthetic rate $\left(\mathrm{P}_{\mathrm{n}}\right)$ of anemone and ranunculus plants after irrigating with a nutrient solution at an electrical conductivity (EC) of $0.5 \mathrm{dS} \cdot \mathrm{m}^{-1}$ or a saline solution at ECs of $1.5,2.5,3.5,4.5$, or $5.5 \mathrm{dS} \cdot \mathrm{m}^{-1}$ in a Utah greenhouse in 2021 .

\begin{tabular}{|c|c|c|c|c|c|c|c|c|}
\hline Species & $\begin{array}{c}\mathrm{EC} \\
\left(\mathrm{dS} \cdot \mathrm{m}^{-1}\right)^{\mathrm{z}} \\
\end{array}$ & $\begin{array}{c}\text { Leaves } \\
\text { (no.) }\end{array}$ & $\begin{array}{c}\text { Growth } \\
\text { index }(\mathrm{cm})^{\mathrm{z}}\end{array}$ & $\begin{array}{c}\text { Shoot } \\
\text { DW }(g)^{z}\end{array}$ & CCI & $\left(\mathrm{mmol} \cdot \mathrm{m}^{-2} \cdot \mathrm{s}^{-1}\right)$ & $\begin{array}{c}E \\
\left(\mathrm{mmol} \cdot \mathrm{m}^{-2} \cdot \mathrm{s}^{-1}\right)\end{array}$ & $\begin{array}{c}P_{n_{n}} \\
\left(\mu \mathrm{mol} \cdot \mathrm{m}^{-2} \cdot \mathrm{s}^{-1}\right) \\
\end{array}$ \\
\hline \multirow[t]{5}{*}{ Anemone } & 0.5 & 7.5 & 21.8 & 3.9 & 9.9 & 95.1 & 1.74 & 6.05 \\
\hline & 2.5 & 9.3 & 20.0 & 4.2 & 6.4 & 27.1 & 0.54 & 1.12 \\
\hline & 4.5 & 8.8 & 21.0 & 4.4 & 5.1 & 20.4 & 0.43 & 0.48 \\
\hline & Linear & NS & NS & NS & NS & $*$ & $*$ & $* *$ \\
\hline & Quadratic & NS & NS & NS & NS & NS & NS & NS \\
\hline \multirow{6}{*}{ Ranunculus } & 2.5 & 14.9 & 16.2 & 2.4 & 16.2 & 138.0 & 2.41 & 4.48 \\
\hline & 3.5 & 13.9 & 15.9 & 2.5 & 16.9 & 98.9 & 1.72 & 2.62 \\
\hline & 4.5 & 14.4 & 17.4 & 2.8 & 12.5 & 73.4 & 1.30 & 4.18 \\
\hline & 5.5 & 13.8 & 16.6 & 2.4 & 12.8 & 99.8 & 1.80 & 4.14 \\
\hline & Linear & NS & $* *$ & NS & NS & NS & 0.06 & NS \\
\hline & Quadratic & NS & $* *$ & NS & NS & NS & NS & NS \\
\hline
\end{tabular}

${ }^{\mathrm{z}} 1 \mathrm{dS} \cdot \mathrm{m}^{-1}=1 \mathrm{mmho} / \mathrm{cm}, 1 \mathrm{~cm}=0.3937 \mathrm{inch}, 1 \mathrm{~g}=0.0353 \mathrm{oz}$.

Ns, *,**Nonsignificant or significant at $P<0.05$ or 0.01 , respectively.

and ranunculus plants tend not to experience much additional vegetative growth after flowering is initiated (Horovitz, 1985a, 1985b).

Visual quality at the end of the experiment decreased from 3 to 1 for anemone and from 3 to 2 for ranunculus as EC increased from 0.5 to $4.5 \mathrm{dS} \cdot \mathrm{m}^{-1}$ and 0.5 to $5.5 \mathrm{dS} \cdot \mathrm{m}^{-1}$, respectively (Fig. 1). The average visual quality scores across all treatments were $2 \pm 1$ for anemone and $3 \pm 1$ for ranunculus. In both crops, visual quality scores decreased over time as browning began on the edges of leaves and progressed to the middle of the leaves and stems. Ranunculus plants had greater visual scores than anemones on average because discoloration was more often confined to the edges of the ranunculus leaves, whereas the entirety of the anemone leaves was affected more commonly (Fig. 2). Based on visual quality alone, the irrigation salinity tolerance threshold for both anemone and ranunculus is likely between 0.5 and $2.5 \mathrm{dS} \cdot \mathrm{m}^{-1}$, assuming a leaching fraction of $\approx 20 \%$, because significant decreases in visual quality occurred when plants were irrigated with an EC of $2.5 \mathrm{dS} \cdot \mathrm{m}^{-1}$ or more.

LEAF GREENNESS AND GAS EXCHANGE. In anemone, leaf greenness [chlorophyll content index (CCI)] decreased from 9.9 to 5.1 as EC increased from 0.5 to $4.5 \mathrm{dS} \cdot \mathrm{m}^{-1}(P=$ 0.07); CCI decreased in ranunculus from 23.1 to 12.8 as EC increased from 0.5 to $5.5 \mathrm{dS} \cdot \mathrm{m}^{-1}(P=0.05)$ (Table 2). In anemone, gs decreased from 95.1 to $20.4 \mathrm{mmol} \cdot \mathrm{m}^{-2} \cdot \mathrm{s}^{-1}(P=$ 0.03 ) and $E$ decreased from 1.74 to $0.43 \mathrm{mmol} \cdot \mathrm{m}^{-2} \cdot \mathrm{s}^{-1}(P=0.02)$ as EC increased from 0.5 to $4.5 \mathrm{dS} \cdot \mathrm{m}^{-1}$. In ranunculus, $g_{S}$ decreased from 121.6 to $99.8 \mathrm{mmol} \cdot \mathrm{m}^{-2} \cdot \mathrm{s}^{-1}$ as EC increased from 0.5 to $5.5 \mathrm{dS} \cdot \mathrm{m}^{-1}$, but this result was not statistically significant. Transpiration decreased from 2.34 to 1.80 $\mathrm{mmol} \cdot \mathrm{m}^{-2} \cdot \mathrm{s}^{-1}$ as EC increased from 0.5 to $5.5 \mathrm{dS} \cdot \mathrm{m}^{-1}$ for ranunculus $(P=$ $0.06)$. Decreased $g_{S}$ and $E$, indicative of a water deficit within the plant, are consistent with the expected effects of osmotic stress resulting from salt accumulating in the plant root zone

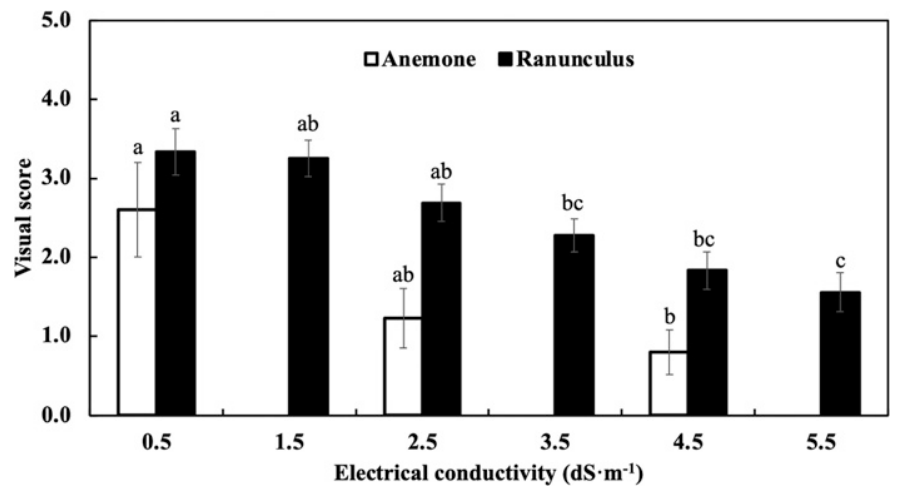

Fig. 1. Visual score of anemone and ranunculus plants after irrigating with a nutrient solution at an electrical conductivity (EC) of $0.5 \mathrm{dS} \cdot \mathrm{m}^{-1}$ or a saline solution at ECs of $1.5,2.5,3.5,4.5$, or $5.5 \mathrm{dS} \cdot \mathrm{m}^{-1}$ for eight applications in a Utah greenhouse in 2021 . Visual score reference scale: 0 , dead; 1 , severe foliar damage ( $>90 \%$ leaves with burnt edges, necrosis, and yellowing); 2 , moderate foliar damage $(50 \%$ to $90 \%) ; 3$, slight foliar damage $(10 \%$ to $50 \%) ; 4$, good quality with minimal foliar damage $(<10 \%) ; 5$, excellent without foliar damage.

Lowercase letters represent significance differences $(P<0.05)$ among treatments within each species using a Tukey's honestly significant difference test. Vertical bars represent $\mathrm{SE} ; 1 \mathrm{dS} \cdot \mathrm{m}^{-1}=1 \mathrm{mmho} / \mathrm{cm}$. 

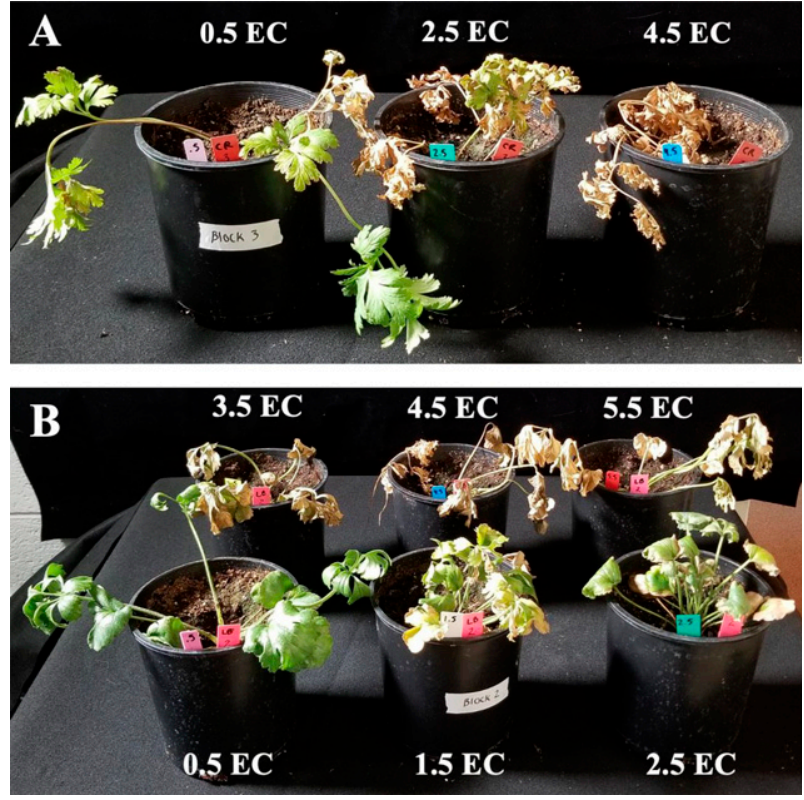

Fig. 2. Images of (A) anemone and (B) ranunculus plants after irrigating with a nutrient solution at an electrical conductivity (EC) of $0.5 \mathrm{dS} \cdot \mathrm{m}^{-1}$ or a saline solution at ECs of $1.5,2.5,3.5,4.5$, or $5.5 \mathrm{dS} \cdot \mathrm{m}^{-1}$ for eight applications in a Utah greenhouse in $2021 ; 1 \mathrm{dS} \cdot \mathrm{m}^{-1}=1 \mathrm{mmho} / \mathrm{cm}$. other crops. However, this temperature range is representative of field conditions in late spring along Utah's Wasatch Front, where daytime temperatures averaged $20 \pm 5^{\circ} \mathrm{C}$ and nighttime temperatures averaged $13 \pm 4^{\circ} \mathrm{C}$ in May 2021 for Murray, UT (Utah Climate Center, 2021). Total yields ranged from one to two stems per plant for ranunculus and two to three stems per plant for anemone, whereas marketable yields ranged from one to two stems per plant for both species. Ranunculus marketable yields are consistent with the one to three stems per plant obtained by Valdez-Aguilar et al. (2009), but total yields are low compared with the three to five total stems per plant obtained in a field production trial by Wien (2015), and the 9 to 15 total stems/plant predicted by the tuber supplier for tubers of the 5- to 7$\mathrm{cm}$ size used in our study (Fred C. Gloeckner and Co.). Similarly, marketable anemone yields were low compared with the average four stems per plant obtained by Bernstein et al.
CUT FLOWER BLOOM TIMING AND YIELD. The blooming period lasted $44 \mathrm{~d}$ for anemone and $26 \mathrm{~d}$ for ranunculus. The ranunculus blooming period was longer than the blooming period of $17 \mathrm{~d}$ obtained by ValdezAguilar et al. (2009), but low compared with field production with protected cultivation methods, such as the $78 \mathrm{~d}$ obtained by Stock et al. (2020) in northern Utah or the $77 \mathrm{~d}$ obtained by Bernstein et al. (2018) in Israel. The below-average duration of blooms obtained in our study and by that of Valdez-Aguilar et al. (2009) is likely indicative of salinity stress, as flowering would logically be limited by the reduction in overall plant vigor caused by salt stress (Munns and Tester, 2008).

The impact of increasing salinity on marketable and total yield was insignificant for both species tested (Fig. 3). Cut flower yield in tuberous species, such as anemone and ranunculus, is generally considered a factor of tuber size and environmental factors-mainly, temperature, light, and moisture (De Hertogh and Le Nard, 1993). Anemone and ranunculus prefer a day/night temperature range of 12 to $16 / 7$ to $10^{\circ} \mathrm{C}$ (Armitage and Laushman, 2003; De Hertogh, 1996), but the greenhouse temperature in our study was maintained at $20 / 16^{\circ} \mathrm{C}$ because the space was shared with
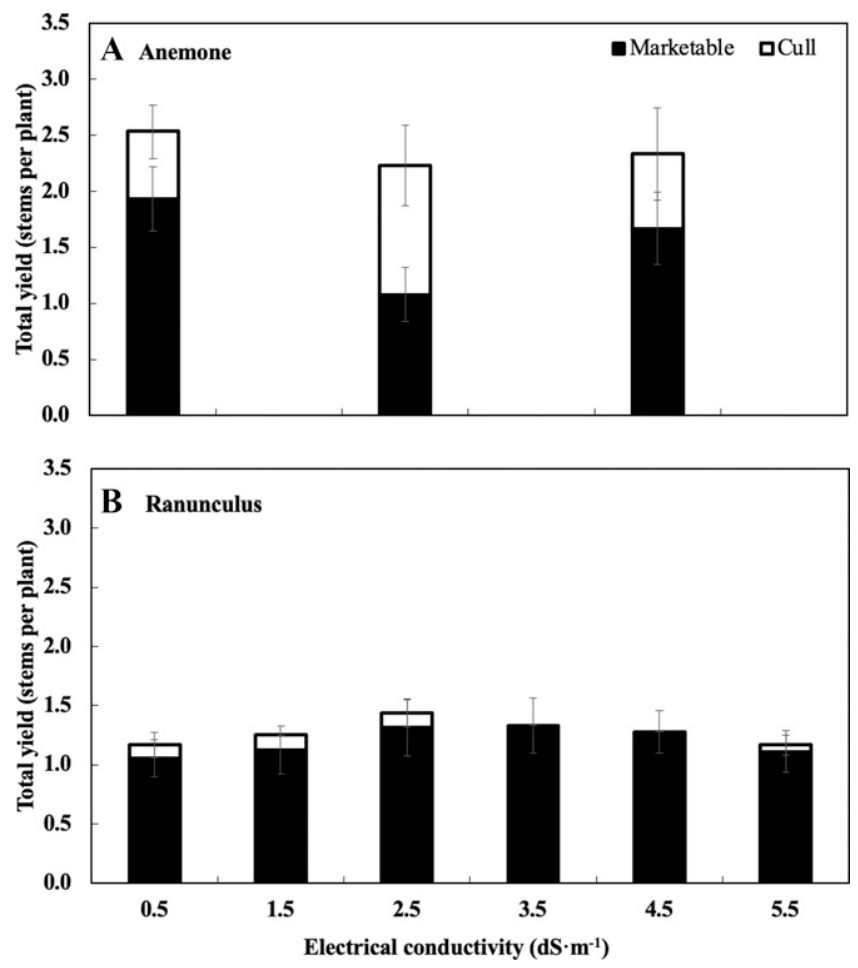

Fig. 3. Total yield in stems per plant of (A) anemone and (B) ranunculus after irrigating with a nutrient solution at an electrical conductivity (EC) of 0.5 $\mathrm{dS} \cdot \mathrm{m}^{-1}$ or saline solution at ECs of $1.5,2.5,3.5,4.5$, or $5.5 \mathrm{dS} \cdot \mathrm{m}^{-1}$ for eight applications in a Utah greenhouse in 2021. The total yield is the sum of the marketable yield (black bars) and cull yield (white bars). Based on local market preferences and seasonality, straight stems a minimum of $15 \mathrm{~cm}$ (5.9 inches) in length were considered marketable whereas cull stems were any stems shorter than $15 \mathrm{~cm}$, with excessive curvature, or with visible deformities (A. Harrison, personal communication). Vertical bars represent $\mathrm{SE} ; 1 \mathrm{dS} \cdot \mathrm{m}^{-1}=1 \mathrm{mmho} / \mathrm{cm}$. 
(2018), and total yields were low compared with the potential 13 to 15 stems per plant described by breeders (Laura and Allavena, 2007). The total yields for both species, across all salinity treatments, are likely less than the yields obtained in the aforementioned studies with tubers of the same size because of the above-optimal greenhouse temperatures. The percentage of cull blooms was $30 \% \pm 18 \%$ for anemone, which is consistent with the $25 \%$ obtained by Bernstein et al. (2018), and the result of noticeable discoloration on the blooms that prevented stems from being marketable regardless of stem length. The percentage of cull blooms was much less, at $4 \% \pm 4 \%$, for ranunculus. Valdez-Aguilar et al. (2009) did not report any ranunculus cull blooms in their study, but categorized blooms as marketable based only on stem length, without considering bloom quality.

LEACHATE AND SUBSTRATE EC. For each salinity treatment, leachate and substrate EC were not noticeably different across species; therefore, data were averaged across species. The average leaching fraction across eight applications was $21.36 \% \pm 8.86 \%$, and leachate ECs were greater than the EC of the irrigation solution in all treatments, including the control (Fig. 4). Leachate EC of control plants ranged from 0.57 to $1.67 \mathrm{dS} \cdot \mathrm{m}^{-1}$, and the ECs of the leachate from treatments increased from 1.42 to $2.08,1.94$ to $3.28,2.62$ to $5.19,2.72$ to 5.57 , and 3.47 to $7.25 \mathrm{dS} \cdot \mathrm{m}^{-1}$ after eight applications of saline solutions with an EC of $1.5,2.5,3.5,4.5$, and $5.5 \mathrm{dS} \cdot \mathrm{m}^{-1}$, respectively. Substrate EC at the end of the experiment increased with increasing salinity of irrigation solution, from $1.06 \pm 0.60 \mathrm{dS} \cdot \mathrm{m}^{-1}$ for the control to $9.11 \pm 1.96 \mathrm{dS} \cdot \mathrm{m}^{-1}$ for EC $5.5 \mathrm{dS} \cdot \mathrm{m}^{-1}$ (Table 3$)$. The increase in leachate EC over time and increased substrate EC compared with irrigation solution EC are consistent with previous observations that irrigation with saline water leads to accumulation of salts in the plant rhizosphere (Ayers and Westcot, 1985; Paudel et al., 2019; Wu et al., 2016). The observed accumulation of salts in the substrate likely accounts for the decreased visual quality, CCI, and $E$ in both species, as well as decreased $g_{S}$ and $P_{n}$ in anemone and decreased growth in ranunculus.

Substrate EC was about double the irrigation solution EC for all

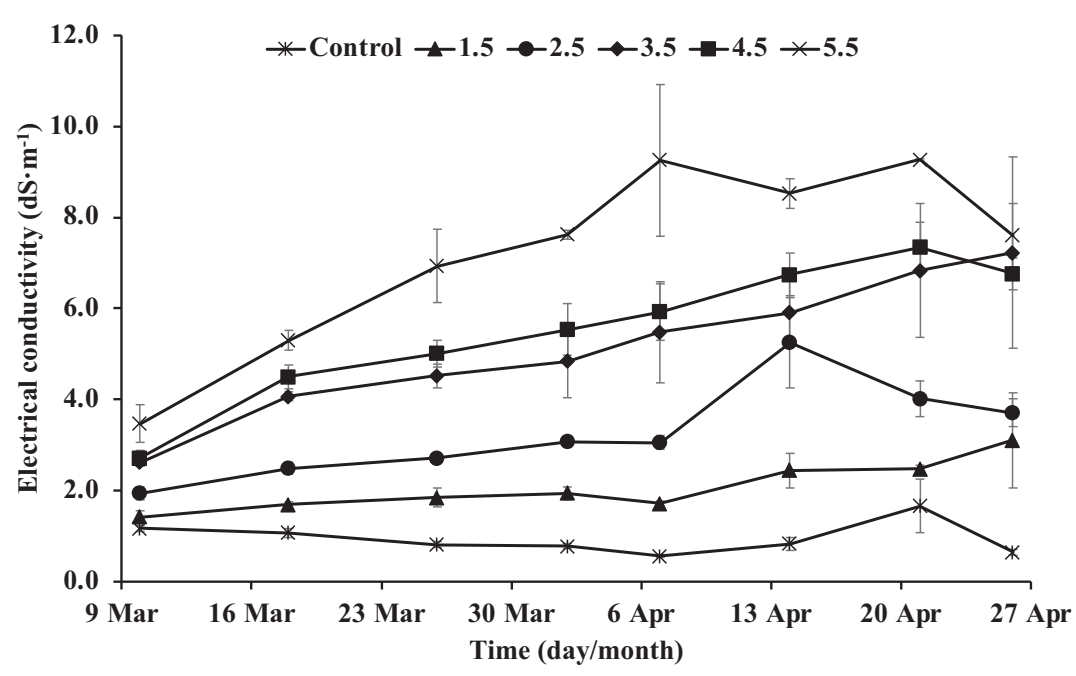

Fig. 4. Electrical conductivity (EC) of leachate solution collected after irrigating anemone and ranunculus plants with a nutrient solution at an EC of $0.5 \mathrm{dS} \cdot \mathrm{m}^{-1}$ or a saline solution at an EC of $1.5,2.5,3.5,4.5$, or $5.5 \mathrm{dS} \cdot \mathrm{m}^{-1}$ in a Utah greenhouse in 2021. The nutrient solution was prepared by adding $0.4 \mathrm{~g} \cdot \mathrm{L}^{-1}(400 \mathrm{ppm})$

$15 \mathrm{~N}-2.2 \mathrm{P}-12.5 \mathrm{~K}$ water-soluble fertilizer to reverse-osmosis water. Sodium chloride and calcium chloride dihydrate were added to the nutrient solution to make the saline solutions. Vertical bars represent the SE of eight measurements, four plants per treatment per species; $1 \mathrm{dS} \cdot \mathrm{m}^{-1}=1 \mathrm{mmho} / \mathrm{cm}$.

treatments, including the control. According to Ayers and Westcot (1985), a leaching fraction of $20 \%$ should result in a soil EC 1.3 times greater than the irrigation solution EC, with the calculated soil EC value representing an average of the entire root zone. In this case, measured substrate EC values represented the top portion of soilless media after drying and upward movement of salts occurred, so

Table 3. Average electrical conductivity (EC) of the soilless media from each irrigation solution treatment after eight treatments on anemone and ranunculus in a Utah greenhouse in 2021. Saturated soil paste technique (Gavlak et al., 1994) was used for determining the substrate EC and results were pooled across cultivars and species.

\begin{tabular}{|c|c|}
\hline EC & Substrate EC $($ mean $\pm S E)$ \\
\hline \multicolumn{2}{|r|}{$\left(\mathrm{d} S \cdot \mathrm{m}^{-1}\right)^{\mathrm{z}}$} \\
\hline 0.5 & $1.06 \pm 0.15$ \\
\hline 1.5 & $2.60 \pm 0.21$ \\
\hline 2.5 & $4.94 \pm 0.66$ \\
\hline 3.5 & $7.66 \pm 0.85$ \\
\hline 4.5 & $9.72 \pm 0.44$ \\
\hline 5.5 & $9.11 \pm 0.69$ \\
\hline Linear & $* * *$ \\
\hline Quadratic & NS \\
\hline
\end{tabular}

it is logical that substrate EC values were consistently greater than would be predicted by the literature for most soils. In soil tests of 33 small, urban farms across Utah's Wasatch Front, soil EC ranged from 0.93 to $5.80 \mathrm{dS} \cdot \mathrm{m}^{-1}$, with an average EC of $2.51 \pm 1.17$ $\mathrm{dS} \cdot \mathrm{m}^{-1}$ (M. Stock, unpublished data). The soil EC range encountered in Utah indicates that the substrate ECs to which anemone and ranunculus plants were subjected in our study are representative of both current and potential field conditions, because soil EC values across the Wasatch Front appear to be increasing gradually.

\section{Conclusion}

After eight irrigation treatments, the EC of soilless media for all treatments and the control was about double the EC of the irrigation solution. As a result of this increasing salinity in the root zone, ranunculus visual quality, growth, leaf greenness, and $E$ decreased as irrigation solution EC increased from 0.5 to $5.5 \mathrm{dS} \cdot \mathrm{m}^{-1}$, which is consistent with the findings of Valdez-Aguilar et al. (2009) that ranunculus is sensitive to salinity stress. Similarly, anemone visual quality, leaf greenness, $g_{S}, E$, and $P_{n}$ decreased as the irrigation solution EC increased from 0.5 to $4.5 \mathrm{dS} \cdot \mathrm{m}^{-1}$. Based on visual quality alone, the irrigation 
salinity tolerance threshold for both anemone and ranunculus is likely between 0.5 and $2.5 \mathrm{dS} \cdot \mathrm{m}^{-1}$, because significant decreases in visual quality occurred when plants were irrigated with an EC of $2.5 \mathrm{dS} \cdot \mathrm{m}^{-1}$ and more. The soil salinity tolerance threshold is likely higher, within the range of 1 to $5 \mathrm{dS} \cdot \mathrm{m}^{-1}$ that resulted in the substrate after eight treatments with irrigation solution between 0.5 and $2.5 \mathrm{dS} \cdot \mathrm{m}^{-1}$. Based on our findings, both anemone and ranunculus can be considered sensitive to salinity, making these cut flowers poor choices in production systems with a risk of elevated soil salinity.

\section{Literature cited}

Armitage, A.M. and J.M. Laushman. 2003. Specialty cut flowers. 2nd ed. Timber Press, Portland, OR.

Ayers, R.S. and D.W. Westcot. 1985. Water quality for agriculture. Food and Agriculture Organization, Rome, Italy.

Ben-Hod, G., J. Kigel, and B. Steinitz. 1989. Photothermal effects on corm and flower development in Anemone coronaria L. Scientia Hort. 40:247-258, https://doi. org/10.1016/0304-4238(89)90117-9.

Bernstein, N., M. Sacks, P. Snir, and R. Rosenberg. 2018. Prevention of flower abortion and leaf damages in Anemone coronaria by Ca supplements. Isr. J. Plant Sci. 65:97-108, https://doi.org/10.1163/ 22238980-00001038.

Bugbee, G.J. 2002. Growth of ornamental plants in container media amended with biosolids compost. Compost Sci. Util. 10:92-98, https://doi.org/10.1080/106 5657X.2002.10702069.

Carter, C.T. and C.M. Grieve. 2008. Salt tolerance of floriculture crops, p. 279-287. In: M.A. Kahn and D.J. Weber (eds.). Ecophysiology of high salinity tolerant plants. Springer, Dordrecht, The Netherlands.

Cavins, T.O., B.E. Whipker, and W.C. Fonteno. 2008. PourThru: A method for monitoring nutrition in the greenhouse. Acta Hort. 779:289-297, https://doi. org/10.17660/ActaHortic.2008.779.35.

Cerveny, C.B., W.B. Miller, and A.G. Taylor. 2011. Storage temperature and moisture content affect respiration and survival of Ranunculus asiaticus dry tuberous roots. HortScience 46:1523-1527, https://doi. org/10.21273/HORTSCI.46.11.1523.

Cerveny, C.B., W.B. Miller, T. Björkman, and N.S. Mattson. 2012. Soaking temperature of dried tuberous roots influences hydration kinetics and growth of Ranunculus asiaticus (L.). HortScience 47:212-216,
https://doi.org/10.21273/HORTSCI.47. 2.212 .

De Hertogh, A.A. 1996. Holland bulb forcer's guide. 5th ed. Alkemade Printing, Lisse, The Netherlands.

De Hertogh, A.A. and M. Le Nard. 1993. The physiology of flower bulbs. Elsevier Science Publishers, Amsterdam, The Netherlands.

Dolatkhahi, A., M. Shoor, M. Bannayan, A. Tehranifar, and A. Alizadeh. 2020. Water deficit decreases gas exchange parameters and marketable quality of Rosa bybrida 'Club-Nika' irrespective of training systems. J. Agr. Sci. Technol. 22:837-849.

Gavlak, R.G., D.A. Horneck, and R.O. Miller. 1994. Plant, soil, and water reference methods for the western region. Western Regional Ext. Pub. (WREP) 125.

Grieve, C.M. 2011. Salinity-induced enhancement of horticultural crop quality, p. 1173-1194. In: M. Pessarakli (ed.). Handbook of plant and crop stress. Taylor and Francis, Boca Raton, FL.

Grieve, C.M., J.A. Poss, P.J. Shouse, and C.T. Carter. 2008. Modeling growth of Matthiola incana in response to saline wastewaters differing in nitrogen level. HortScience 43:1787-1793, https://doi. org/10.21273/HORTSCI.43.6.1787.

Grieve, C.M., L.E. Francois, and E.V. Maas. 1994. Salinity affects the timing of phasic development in spring wheat. Crop Sci. 34:1544-1549, https://doi.org/10.2135/ cropscil994.0011183X003400060024x.

Horovitz, A. 1985a. Anemone coronaria and related species, p. 455-464. In: A.H. Halevy (ed.). Handbook of flowering. Vol. I. CRC Press, Boca Raton, FL.

Horovitz, A. 1985b. Ranunculus, p. 155-161. In: A.H. Halevy (ed.). Handbook of flowering. Vol. IV. CRC Press, Boca Raton, FL.

Kelly, J.W. 1991. Field production of cut flowers. HortScience 26:1136-1138, https://doi.org/10.21273/HORTSCI.26. 9.1136.

Laura, M. and A. Allavena. 2007. Anemone coronaria breeding: Current status and perspectives. Eur. J. Hort. Sci. 72:241-247.

Lewis, M., M. Stock, B. Black, D. Drost, and X. Dai. 2021. Improving snapdragon cut flower production through high tunnel season extension, transplant timing, and cultivar selection. HortScience, https:// doi.org/10.21273/HORTSCI15910-21.

Maas, E.V. and S.R. Grattan. 1999. Crop yields as affected by salinity. Agr. Drainage 38:55-108, https://doi.org/10.2134/ agronmonogr38.c3.
Maas, E.V. and G.J. Hoffman. 1977. Crop salt tolerance: Current assessment. J. Irr. Drainage Div. 103:115-134, https:// doi.org/10.1061/JRCEA4.0001137.

Munns, R. and M. Tester. 2008. Mechanisms of salinity tolerance. Annu. Rev. Plant Biol. 59:651-681, https://doi.org/ 10.1146/annurev.arplant.59.032607.09 2911.

Niu, G. and R.I. Cabrera. 2010. Growth and physiological responses of landscape plants to saline water irrigation: A review. HortScience 45:1605-1609, https://doi. org/10.21273/HORTSCI.45.11.1605.

Ohkawa, K. 1986. Growth and flowering of Ranunculus asiaticus. Acta Hort. 17:165-172, https://doi.org/10.17660/ ActaHortic.1986.177.22.

Parrella, G., P. Gognalons, K.G. Selassie, C. Vovlas, and G. Marchoux. 2003. An update of the host range of tomato spotted wilt virus. J. Plant Pathol. 85:227-264.

Paudel, A., J.J. Chen, Y. Sun, Y. Wang, and R. Anderson. 2019. Salt tolerance of Sego Supreme ${ }^{\mathrm{TM}}$ plants. HortScience 54:20562062, https://doi.org/10.21273/HORT SCI14342-19.

Pitman, M.G. and A. Läuchli. 2002. Global impact of salinity and agricultural ecosystems, p. 3-20. In: A. Läuchli and U. Lüttge (eds.). Salinity: Environmentplants-molecules. Springer, Dordrecht, The Netherlands.

Prisco, J.T., E. Gomes Filho, and R. de S. Miranda. 2016. Physiology and biochemistry of plants growing under salt stress, $\mathrm{p}$. 1-17. In: H.R. N. da S. Dias Gheyi, C.F. de Lacerda, and E. Gomes Filho (eds.). Manejo da salinidade na agricultura: Estudos baìsicos e aplicados. Instituto Nacional de Ciência e Tecnologia em Salinidade (INCTSal), Fortaleza, CE, Brazil.

Shillo, R., M. Ding, D. Pasternak, and M. Zaccai. 2002. Cultivation of cut flower and bulb species with saline water. Scientia Hort. 92:41-54, https://doi.org/ 10.1016/S0304-4238(01)00276-X.

Stewart, A. 2007. Flower confidential: The good, the bad, and the beautiful in the business of flowers. Algonquin Books, Chapel Hill, NC.

Stock, M., K. Wagner, S. Hansen, B. Black, and D. Drost. 2020. Evaluating production strategies for ranunculus in the intermountain west. Cut Flower Qrtly. 32(4):27-30.

Sun, Y., G. Niu, and C. Perez. 2015. Relative salt tolerance of seven Texas Superstar ${ }^{\circledR}$ perennials. HortScience 50:1562-1566, https://doi.org/10.21273/HORTSCI.50. 10.1562 . 
Tanji, K.K. 2002. Salinity in the soil environment, p. 21-51. In: A. Läuchli and U. Lüttge (eds.). Salinity: Environmentplants-molecules. Springer, Dordrecht, The Netherlands.

Utah Climate Center. 2021. Murray, UT. 8 Sept. 2021. <https://climate.usu.edu/ mchd/dashboard/dashboard.php?network= AGWX\&station $=1138094 \&$ startdate $=2021$ 01-12T02:46:28.894Z\&enddate $=2021-02$ 11T02:46:28.894Z\&units=E\&showgraph= $0 \&>$.
Valdez-Aguilar, L.A., C.M. Grieve, J.A. Poss, and M.A. Mellano. 2009. Hypersensitivity of Ranunculus asiaticus to salinity and alkaline $\mathrm{pH}$ in irrigation water in sand cultures. HortScience 44:138-144, https://doi.org/10.21273/HORTSCI. 44.1.138.

Wien, H.C. 2015. Cut flower cultural practice studies and variety trials 2015. 2 July 2021 . <http://www.hort.cornell.edu/wien/cut flowers/reports/2015cutflowerreport. pdf $>$.
Wu, S., Y. Sun, and G. Niu. 2016. Morphological and physiological responses of nine ornamental species to saline irrigation water. HortScience 51:285-290, https://doi.org/10.21273/HORTSCI. 51.3.285

Yue, C. and C. Hall. 2010. Traditional or specialty cut flowers? Estimating U.S. consumers' choice of cut flowers at noncalendar occasions. HortScience 45:382-386, https://doi.org/10.21273/HORTSCI.45. 3.382 . 